\author{
Rybinska Yulia \\ Doctor of Education, Professor, \\ Head of the Department of Foreign Philology \\ of Kyiv National University of Culture and Arts \\ Julialeo1619@gmail.ru \\ ORCID 0000-0002-2982-8245 \\ Researcher ID: M-3781-2018
}

\title{
INTEGRATION OF CULTURES AS A 21ST CENTURY PHENOMENON
}

The purpose of the article is to examine the main characteristics of multiculturalism and ways of solving multicultural problems in the globalized world of the XXI century and to show the current trends of integration during the global processes of globalization. The methodology of the research is based on comparative and analytical methods, which are accompanied by natural observations. For a multicultural society, a common space and sometimes even culture is characteristic. This can have different advantages, but on the other hand, it is a threat to the emergence of problems and conflicts. The scientific novelty of the work consists in expanding knowledge about integration processes as a phenomenon of the XXI century, which is focused on the integration of the intercultural society and multiculturalism. A detailed analysis emphasizes the synthesis of the advantages and disadvantages of these processes. Conclusions. The article is a study, in which the author compares various cultures in many societies and tries to find a possible solution to problems that arise in intercultural communities, and thus can create new ways of solving actual problems. In particular, such issues deserve particular attention as: integration of countries in the era of globalization at the regional level; existing integration models; successes and challenges; new stages of integration in the world. A general description of the significance and importance of the concept "culture" and "cultural diversity" in business organizations is presented. The effectiveness of scientific research that studies the diversity of cultures is generally proved. On the eve of this study, a general assessment of the cultural course in organizational and business literature was conducted. It has been statistically proved that the indicators of the integration of cultures have increased significantly in the 21 st century. A deep understanding of integration as a phenomenon of the 21 st century will provide a constructive understanding of the world as a whole. In addition, international integration will contribute to the important elements of social progress, such as interethnic public benefits and economic growth.

Key words: integration processes, globalization and regionalization, cultural integration, assimilation, cultural identity, multiculturalism, intercultural society, pluralism.

Рибінська Юлія Анатоліївна, доктор педагогічних наук, дочент, завідувач кафедри іноземної фрілології Київського національного університету культури і мистецтв

Інтеграція культур як феномен XXI століття

Мета статті - розглянути основні характеристики мультикультуралізму та способи розв'язання мультикультурних проблем у глобалізованому світі XXI століття, показати сучасні тенденції інтеграції впродовж світових процесів глобалізації. Методологія дослідження базується на порівняльному та аналітичному методах, що супроводжуються емпіричними спостереженнями. Для полікультурного суспільства характерний спільний простір та подекуди навіть культура. Це може створювати різні переваги, але, з іншого боку, це несе загрозу виникнення проблем та конфлліктів. Наукова новизна роботи полягає у розширенні знань про інтеграційні процеси як феномену XXI століття, який сконцентрований на інтеграції міжкультурного суспільства та полікультурності. Детальний аналіз підкреслює синтез переваг та недоліків цих процесів. Висновки. У статті проведено дослідження, в якому автор порівнює різноманітні культури у багатьох суспільствах та намагається знайти можливе вирішення проблем, які виникають у міжкультурних спільнотах, а, отже, можуть створювати нові шляхи вирішення актуальних проблем. Зокрема, такі питання заслуговують особливої уваги: інтеграція країн у добу глобалізації на регіональному рівні; існуючі моделі інтеграції; успіхи та виклики; нові етапи інтеграції у світі. Подається загальний опис значення та важливості концепту «культура» та «культурне різноманіття» у бізнесових організаціях. Загально доведеною $€$ ефрективність наукового дослідження, що вивчає різноманіття культур. Напередодні цього дослідження проводилась загальна оцінка курсу культури в організаційній та бізнес-літературі. Статистично доведено, що показники інтеграції культур значно збільшилися у XXI столітті. Глибоке розуміння інтеграції як феномену XXI століття забезпечить конструктивне розуміння світу загалом. До того ж, міжнародна інтеграція сприятиме забезпеченню важливих елементів суспільного прогресу, таких, як міжнаціональні громадські блага та економічне зростання.

Ключові слова: інтеграційні процеси, глобалізація та регіоналізація, культурна інтеграція, асиміляція, культурна ідентичність, полікультурність, міжкультурне суспільство, плюралізм.

Рыбинская Юлия Анатольевна, доктор педагогических наук, доцент, заведующая кафедры иностранной филологии Киевского национального университета культуры и искусств

Интеграция культур как феномен XXI века

Цель статьи - рассмотреть основные характеристики мультикультурализма и способы решения мультикультурных проблем в глобализированном мире XXI века, показать современные тенденции интеграции в течение мировых процессов глобализации. Методология исследования базируется на сравнительном и аналитическом методах, сопровождающиеся натуральными наблюдениями. Для поликультурного общества характерен общее пространство и иногда даже культура. Это может создавать различные преимущества, но с другой стороны, это несет угрозу возникновения проблем и конфлликтов. Научная новизна работы заключается в расширении 
знаний об интеграционных процессах как феномена XX века, сконцентрирован на интеграции межкультурного общества и поликультурности. Детальный анализ подчеркивает синтез преимуществ и недостатков этих процессов. Выводы. В статье проведено исследование, в котором автор сравнивает различные культуры во многих обществах и пытается найти возможное решение проблем, возникающих в межкультурных сообществах, а следовательно могут создавать новые пути решения актуальных проблем. В частности, такие вопросы заслуживают особого внимания: интеграция стран в эпоху глобализации на региональном уровне; существующие модели интеграции; успехи и вызовы; новые этапы интеграции в мире. Подается общее описание значения и важности концепта «культура» и «культурное многообразие» в бизнес организациях. Обще доказанной является эффективность научного исследования, изучающая многообразие культур. Накануне этого исследования проводилась общая оценка курса культуры в организационной и бизнес-литературе. Статистически доказано, что показатели интеграции культур значительно увеличились в XXI веке. Глубокое понимание интеграции как феномена XXI века обеспечит конструктивное понимание мира в целом. К тому же, международная интеграция будет способствовать обеспечению важных элементов общественного прогресса, как межнациональные общественные блага и экономический рост.

Ключевые слова: интеграционные процессы, глобализация и регионализация, культурная интеграция, ассимиляция, культурная идентичность, поликультурнисть, межкультурное общество, плюрализм.

The current world is more and more both culturally and technologically improving. The consequences of globalization can be found in many spheres of everyday life. International migration is very strong and this trend will continue. The current world can be characterized by local and global problems. Thanks to technical equipment we know what is going all over the world. The coexistence of various cultures and races in multicultural society is not simple and brings many questions and needs appropriate solutions. Factors that ensure the development of the world are multifaceted. One of the fundamental factors, which are the primary stipulation for all the others of them, is integration processes. The 21 st century is characterized by a growing scientific interest to the study on the essence of the process of integration, as well as the development of interstate relations. Today the world lives a new, large-scale "wave of integration» and the process of globalization gave impetus to them. Methodology of the research is based on the comparative and analytical methods followed by the natural observations.

The purpose of the article is to show the contemporary trends of the integration process in the time of the recent globalization in the world. The expansion of integration problem from the level of concrete practical reality of development in the world to the level of a vital issue, which determines the turning points of the domestic and foreign policy of states, has become one of the leading trends observed in the last half of the century. The need for the reality and perspectives of the rapid integration processes in the near and far distance, the choice of the main growth vectors in the context of the new geopolitical reality, as well as the determination of the optimum format of bilateral relations and cooperation with English-speaking countries in changing conditions, require the science-based concept of these processes. The phenomenon of the multicultural society is inevitable cultural diversity. Integration emerged as the terms and theory in the West. But it does not mean that there were no historical experience and models of intercultural relations in other countries around the world.

Scientific novelty of work consists in increasing the knowledge about the integration process as a 21 st century phenomenon, which is focused on the integration intercultural society and multiculturalism.

The current problem was investigated and became the main field of interests for K. Popper, G. Startori, W. Mensing, Ch. Magne, H. Roman and others. The philosophy of integration in a globalizing world is a fundamental issue, which services to find a mechanism for the development and reconciliation of various cultures. So, now people belonging to different cultures face difficulties in choosing communication or identity. There is no alternative to this choice. Integration in Latin means «integer» - «whole, integrity», in fact, the etymology of the word is more clearly states the content and mission of the integration as not only economic, but also political, social, cultural and other processes. Integration is defined as the process of achieving unity of effort among the various subsystems in the accomplishment of the organization's work. In the 21st century, these processes are transiting to super integration model. The result of the process is always uncertain, because the disintegration tendencies always develop in parallel with the integration process. One thing is clear: integration, reintegration and disintegration are processes with objective content and at the result of these processes occurs the restructuring of political and economic, as well as cultural and social architecture of the modern world. Philosophy and strategy of the phenomenon of integration, which has a long history, has changed. The integration is oriented towards global unity not only from the one direction, one culture, but also from all equal subjects of multipolar cultural space. Humanity should appropriately benefit from these processes for its sustainable development and future prospects. Integration is used to prevent trends in intercultural relations - differentiation and assimilation, as well as used for synthesis and harmony. The true ideal of intercultural relations is integration without assimilation. The concept of intercultural or multicultural society first appeared in Switzerland in 1957 and in Germany in the late 1980s. A multicultural society is made up of different nations, cultures, origins, religions, races and languages. Unfortunately, the concept of an intercultural society is too often assimilated with an ideal unattainable in reality. The reason is the coexistence of a large number of different cultures in such society. The Austrian and British philosopher of the 20th century K. R. Popper speaks about a closed and open society. Giovanni Startori considers good society 
to be pluralistic and based on mutual tolerance. It seems that current multicultural society does not mean development of pluralism, but its denial. Multiculturalism does not want differentiated integration. Tolerance and pluralism are two different concepts, even if they are mutually connected. Tolerance respects the values of other people; pluralism promotes its own value. Pluralism states that various opinions will bring positive values for the individual and society. Currently we can speak about two versions of multiculturalism, i. e. multiculturalism, which is influenced by pluralism and the second version of multiculturalism which, is antipluralistic. Pluralism and multiculturalism are not contrary concepts. Multiculturalism can be understood as the existence of various cultures and thus it is just a configuration of pluralism. Multicultural society is characterized by meeting various cultures, nations, languages and religions. The immigrants come to the new country equipped with their own habits and culture. Immigrants are not the people, who come temporarily or commute because of their work. Immigrants are individuals or groups, who leave their own country with the aim of living permanently somewhere else. When a person wants to live in another country, they usually prepare for such a new experience. It is necessary to learn the new language and be aware of the history, politics and culture of the new country. Everything new is usually cold, dangerous and threatening. People of various cultures meet with each other and have to deal with each other, with new situations and experiences. Culture is multifaceted, dynamic and various. Original meaning of the word culture comes from the Latin word colere, which meant looking after as in agriculture, i. e. looking after the field. The word has changed its meaning many times. Culture can be understood as a synonym for sharing the ideas about the world. In all groups and human races there are various viewpoints of the world and life. It is very difficult to find exact barriers between particular cultures. In the course of centuries culture and cultural identity have become an important political tool. Intercultural communication means the social interaction of different cultures. These cultures can be represented by both individuals and organizations, social groups, schools, associations, societies and even states. Culture is a set of factors giving a sense and value to human coexistence in a society. It includes religion, social and cultural values, art, education and science. Culture and social development influence each other. However, people often have a lot of prejudices and stereotypes. Just knowledge of cultural distinctions facilitates intercultural communication. As the world is shrinking through globalization, more and more people live and work in the foreign countries and thus they continually come into contact with the people coming from very diversified cultural origins, involving languages, norms, lifestyle, etc. [28]. Improvement and management of the people on a global scale inevitably requires dealing with cultural diversity and the problems regarding this matters of motivation, leadership, productivity, authority, etc. These explanations reveal that most authors agree that culture is a very complex term and difficult to define in words. Groeschl and Doherty (2000) imply that culture consists of numerous elements, of which some are implicit and others are explicit. Social scientists have been inquiring into the relations between culture and behavior for nearly a century. Still, culture is more and more complex, diffuse, fluid or multiplicity in modern terminology. Culture in this perspective is no longer related to basic social correlations, let alone be able to function as a set of basic guiding principles for institutional arrangements in society [27]. In the literary study done related to this topic, it is seen that there is not a consensus on how cultural diversity can be managed, and the topic is handled from very different approaches. Views are related to effective management of, generally, workforce diversity unanimity among the authors. The main reason for this difference can be explained with the evaluation of the fact of cultural diversity by the authors primarily in view of the workforce. For instance, whereas there are some, who consider cultural diversity as an advantage and a source of power, there are also some, who evaluate it as a problem and a difficult issue to manage. Some authors see cultural diversity management as an attempt to create a common culture, in which individuals from different nations and different cultures in an organization can comfortably work together and where differences are not felt [11]. Kidger (2002) indicates that the one of the targets of organizations displaying particularly multinational or super national activity is to create the feeling of a common cultural identity and goal, involving the whole institution and its corresponding departments. The cultural space of the 21 st century formed the background of the new global reality. Emerging global culture system is the new reality that the boundaries of cultural spaces could not reveal. Not all multi-faceted local cultures will easily take place in this new reality. To achieve this, it is necessary to be integrated into all levels - political, socio-economic, cultural, and legal and etc. The new approaches - multicultural, cross cultural, transcultural, poly-cultural, which are known as the «pluralist paradigm» of communication are formed in the global cultural space. When a phenomenon like globalization encompasses several aspects that taken together may have an effect greater than the sum of their constituent parts, it appears logical to assess these effects together. As we have argued, to confront new questions on the essential nature of globalization requires an interdisciplinary approach. Sociologists, critics of science and technology, and economists and others need to work on different dimensions of the same questions. Globalization (as other complex issues do) requires academics and professionals alike to step outside their disciplinary boundaries. The processes of globalization leads to reaction of various cultures willingly or unwillingly, and impacts on their substance and form. The intensity of intercultural integration has raised, on the one hand, the growing attention to the factor of cultural diversity, on the other hand, both theoretical and practical resolution mechanisms and formats of the problem, as well as caused extensive discussions. If we try to summarize, then the existence of three directions or scripts can be mentioned. They are as follows: 1) confrontation (collision); 2) dialogue; 3) «mixing» of local cultures in the hegemony of cultural space. Having said that, no 
state can ensure its existence separately in a globalized world, despite the fact that no matter how powerful it is, but it is integrated into the processes in the world. Europe passed controversial historical processes for the realization of the idea of unity and integration. In early stages those, who established the empires to find the way of unity by wars and fights, dominated (a stage from Charle Magne and the Holy Roman Empire until the French Empire of Napoleon's period). To measure cultural integration, we focus on both objective indicators and self-reported attitudes and values. The main objective indicators of cultural integration we look at are:

- $\quad$ Family arrangement: education gap between partners, age gap between partners;

- $\quad$ Marital status: early marriage, cohabitation, marital status, divorce rate;

- Interethnic marriage rate;

- $\quad$ Fertility rate.

During the last few decades, human dynamics, institutional change, political relations and the global environment have become successively more intertwined.

Such developments are facilitated by the freer trade of more differentiated products as well as by tourism and immigration. Flows of immigration - both legal and illegal - also contribute to today's melting pot societies. Public awareness of issues such as human rights, democracy and gender equality has increased significantly because of the greater access to newspapers, radio, television, telephones, computers and the internet. These developments have arguably led to improved allocative efficiency that, in turn, enhances growth and human development. These increased global economic integration; global forms of governance, globally interlinked social and environmental developments are often referred to as globalization. On the cultural front, there are more international cultural exchanges, the spread of multi-culturalism and greater cultural diversity within many countries. As the world is increasingly becoming a global village, because people's lives despite their location in one place are connected with other parts of the world through the media, globalization has increased interpersonal and international social-cultural exchanges via migration, tourism or exchange studentship. Many homogeneous societies have turned into multicultural communities, in which people from different cultural backgrounds live together [4]. If we look at existing indices, the 'top ten' countries are usually lauded [5]. The analysis of French estimates the integration process by combining three main surveys: the French Labour Force Survey 2005-2007, which provides for the first time the country of origin of the parents, the French Family Survey 1999, which reports detailed data on the family structure of immigrants, and Histoire de Vie 2003 that reports attitudes and values of a representative sample of immigrants. Sociologists have been studying the cultural integration patterns of immigrants at least since the late nineteenth century, especially in the context of immigration into the United States. Economists have instead been traditionally mainly interested in assessing the direct impact of immigration flows on market outcomes (especially on the labour market) or on fiscal transfers and public goods provision. The basic question of assimilation for economists has, then, been framed in terms of economic. Those surveys provide a focus on the integration process of six main groups of immigrants coming from: Maghreb, Sub-Saharian Africa, Southern Europe, Northern and Eastern Europe and Asia. In particular, first-generation immigrants from Maghreb and Africa display significant cultural and economic gaps with natives regarding marriage at early age, age and education gap between spouses or fertility rates. But evidence was found that in almost all dimensions and for all groups, there is a fast integration process between first and second-generation of immigrants. The new National Immigration Survey sampled the foreign-born population residing in Spain in 2007 with the specific aim of providing insights on migrants' experience in Spain. Those surveys distinguish four main origins of immigration: Latin America, Morocco, other Maghreb countries and Eastern Europe. Latinos - the group with the shortest cultural distance to Spain social norms - appear very similar to natives in most of the economic and cultural outcomes. The analysis of integration in the United Kingdom is mainly based on the Labour Force Survey (LFS) for the years 2000-2008 inclusive. The LFS contains information on country of birth, but no information on country of parental birth for the UK born. This means that it is impossible to identify second-generation immigrants. The analysis of the descendants of immigrants is restricted to ethnic minorities. The main immigrant groups are: Indian, Pakistani, Bangladeshi, Black Caribbean, Black African and Chinese. It is significant to find the differences across ethnic minorities in cultural and economic outcomes, but a striking common pattern that emerges is the extent to which the behavior of UK-born ethnic minorities generally lies between that of white natives and the foreign-born from that community. This indicates a general pattern of cultural assimilation. The rate of cultural assimilation is faster for some variables than others it is perhaps religion that shows the slowest rate. But overall there are very powerful forces that are acting to change the behavior of immigrant communities once they are in the United Kingdom. The analysis of the integration process in the United States draws on very detailed information from the Census, starting from 1900 onwards and covering all the countries of origin. The Census allows a unique look at the evolution of the integration process of different minorities since the early twentieth century. It is shown that overall there has been little change in cultural immigration over the past century. But some important changes over time and differences across group emerge. Members of the largest single immigrant group of the early twentieth century, those born in Italy, in general were much less assimilated upon arrival than members of the largest group of the early twenty-first century, those born in Mexico. Whereas one-third of newly arrived Mexicans spoke no English in recent years, nearly three-quarters of newly arrived Italians could not speak English in 
1910. In this way, the growth in transport, for instance, is connected to the exploitation of natural resources. So, while this helps to elevate the Netherlands to the top ranking of this globalization index, it also raises questions about the relationship between globalization, economic growth and the environment. Another example, India, is regarded as one of the most important emerging powers, with impressive growth rates, which seem to have their basis in the recent policies of globalization. However, in this country environmental degradation is of serious concern. Unlike the other variables in the globalization index, the ecological domain appears to be a consequence of globalization rather than a driving force. However, as the globalization processes intensify over time, the "indirect impacts of human-induced disruption of global biogeochemical cycles and global climate change start to become apparent".

Conclusion. The grounded understanding of integration as a 21 st century phenomenon provides with constructive understanding in the contemporary world. In addition, international integration fosters the provision of essential ingredients of societal progress, such as transnational public goods and economic growth. The measurement of international integration, in all its aspects, is increasingly important to a complete understanding of societal well-being and its dynamics. A higher degree of international integration can be seen in itself as an indicator of societal progress, inasmuch as it reveals that human societies more and more acknowledge their common destiny. In addition, international integration fosters the provision of essential ingredients of societal progress, such as trans-national public benefits and economic growth. The rate of cultural integration over time has declined, however. A large ecological footprint implies a large ecological deficit, which needs to be compensated by 'space' outside the country's territory.

\section{תimepamypa}

1. Arts integration in shaping liberal culture of undergraduate students in the USA. Art and Education. 2015. №4. P.51 - 55 .

2. Aslanova, R. Actual problems of cultural integration of Turkic world in XXI century. Gileia: scientific journal: збірник наукових праць. 2016. № 10. С.309-316.

3. Baran, Stanley J. Introduction to Mass Communication: Media Literacy and Culture 2001 Update. California: Mayfild Publishing Company, 2001.519 p.

4. Burity, J. A. (2008), 'Brazil's rise: Inequality, culture and globalization', Futures 40(8), 735-744. 4.

5. Dreher, A. (2006), 'Does globalization affect growth? Evidence from a new index of globalization', Applied Economics 38(10), 1091-1110. 9

6. Clark, W.C. Environmental Globalisation/W.C. Clark (J.S. Nye and J.D. Donahue (eds), Governance in a Globalizing World). Washington: Brookings Institution, 2000. pp.86 - 108.

7. De Lombaerde, P., L. Van Langenhove. Indicators of Regional Integration: Conceptual and Methodological Aspects /De Lombaerde, P., L. Van Langenhove. Assessment and Measurement of Regional Integration, London: Routledge, 2006. pp.9-41.

8. Differences in Cultures. English 4U: The Journal for the one who is learning English. 2009. № 7. pp.24-25.

9. Discovering Ukrainian Culture: Issues in Practice - Ukrainian Culture in English interpretation: for students of higher establishments /ed. Yakiv Bystrov. Vinnytsia: Nova Knyha, 2013. 152 p.

10. Dreher, A. Does Globalization Affect Growth? Evidence from a New Index of Globalization. Research Paper Series: Thurgauer Wirtschaftsinstitut, 2005

-4 . 2002. $464 \mathrm{p}$

11. Duren, A. Z. (1999). Kuresellesen Isletmelerde Kulturel Farkhhklarm Onemi, Yonetim, Vol. 10 No. 33, pp.21

12. Europa von A bis $Z$ : Taschenbuch der europaischen Integration. - Bonn: Europa Union Verlag GmbH,

13. Europe - an area for research: Directorate-General for Education and Culture. - Luxembourg: Office for Official Publications of the European Communities, 2003. $31 \mathrm{p}$.

14. Handbook of technological pedagogical content knowledge (TPCK) for educator. NY - London: Routledge Taylor \& Francis Group, 2008.

15. Harvard Ukrainian Studies: cultures and Nations of Central and Eastern Europe / F. I. Sysyn; Ed. I. Sevcenko. Cambridge: Harvard University Press, 2000.

16. Higgs, M. (1996), "Overcoming the problems of cultural differences to establish success for international management teams", Team Performance Management: An International Journal, Vol. 2 No. 1, pp.36 - 43.

17. Kumar, A. (2008), 'Paradoxes of paradigm shift: Indian engagement with liberalization and globalization', Futures $40(8), 762-766.15$. pp. $23-24$

18. Lukianets, O. Dialogues of Cultures in Action. English language \& culture. Weekly. 2014. January, № 2.

19. Main, G. Peoples of a Spacious Land: Families and Cultures in Colonial New England. Cambridge; London: Harvard University Press, 2004. $316 \mathrm{p}$.

20. Martens, P. \& Rotmans, L. (2005). 'Transitions in a globalizing world', Futures 37, 1133-1144. 4, 15.

21. Martens, P. \& Zywietz, D. (2006), 'Rethinking globalization: a modified globalization index', Journal of International Development 18, 331-350. 5, 9.

22. Morris, M. Multicultural London: Melting pot of cultures. Speak out. 2004. № 6. P.4-5.

23. Pop Culture Versus Real America. New York: Bureau of International Information Programs U.S. Department of State, 2010. $-80 \mathrm{p}$.

24. Role of Media in Promoting European Integration. Kyiv: European Commission, 2001. 88 p.

25. Sysyn, F. I. History, Culture, and Nation: An Examination of Seventeenth-Century Ukrainian History Writing: brochure. Cambridge; Massachusetts: Ukrainian Studies Fund, Inc., 1988. 137 p. 
26. Toorn, Karel van der. Scribal Culture and the Making of the Hebrew Bible. Cambridge; London: Harvard University Press, 2007. 401 p.

27. Vinken, H. (2002), Cultures, Cities and Communications on the Pace and Place of Cultural Change, International ENIGME Workshop "Communication across Cultures in Multicultural Cities", The Hague, 7-8 November, available at: http://www.uvt.nl/iric. Abstract (accessed 4 December 2002).

28. Zakaria, N. (2000), "The effects of cross-cultural training on the acculturation process of the global workforce", International Journal of Manpower, Vol. 21 No. 6, pp. 492-510.

\section{References} 55 [in English].

1. Arts integration in shaping liberal culture of undergraduate students in the USA. (2015). Art and Education,4, 51 -

2. Aslanova, R. (2016). Actual problems of cultural integration of Turkic world in XXI century. Gileia: scientific journal: Zbirnyk naukovyh prats, 10, 309 - 316 [in English].

3. Baran, Stanley J. (2001). Introduction to Mass Communication: Media Literacy and Culture 2001 Update. California: Mayfild Publishing Company [in English].

4. Burity, J. A. (2008), 'Brazil's rise: Inequality, culture and globalization', Futures 40(8), 735-744. 4. [in English].

5. Dreher, A. (2006), 'Does globalization affect growth? Evidence from a new index of globalization', Applied Economics 38(10), 1091-1110. 9 [in English].

6. Clark, W.C. (2000. Environmental Globalisation (J.S. Nye and J.D. Donahue (eds), Governance in a Globalizing World). Washington: Brookings Institution) 86 - 108 [in English].

7. De Lombaerde, P., Van Langenhove L. (2006. Indicators of Regional Integration: Conceptual and Methodological Aspects. Assessment and Measurement of Regional Integration, London: Routledge), 9 - 41 [in English].

8. Differences in Cultures (2009). English 4U: The Journal for the one who is learning English, 7, $24-25$ [in English].

9. Discovering Ukrainian Culture: Issues in Practice - Ukrainian Culture in English interpretation: for students of higher establishments (2013) Yakiv Bystrov. Vinnytsia: Nova Knyha [in English].

10. Dreher, A. (2005). Does Globalization Affect Growth? Evidence from a New Index of Globalization. Research Paper Series: Thurgauer Wirtschaftsinstitut [in English].

11. Duren, A. Z. (1999). Kuresellesen Isletmelerde Kulturel Farkhhklarm Onemi, Yonetim, Vol. 10, 33, 21 - 4 [in Eng-

lish]. English].

12. Europa von A bis Z: Taschenbuch der europaischen Integration (2002). Bonn: Europa Union Verlag GmbH [in

13. Europe - an area for research: Directorate-General for Education and Culture (2003). Luxembourg: Office for Official Publications of the European Communities, [in English].

14. Handbook of technological pedagogical content knowledge (TPCK) for educator (2008). NY - London: Routledge Taylor \& Francis Group [in English].

15. Harvard Ukrainian Studies: cultures and Nations of Central and Eastern Europe (2000). Cambridge: Harvard University Press [in English].

16. Higgs, M. (1996). "Overcoming the problems of cultural differences to establish success for international management teams", Team Performance Management: An International Journal, Vol. 2, 1, 36 - 43 [in English].

17. Kumar, A. (2008), 'Paradoxes of paradigm shift: Indian engagement with liberalization and globalization'. Futures 40(8), 762-766. 15 [in English]. English].

18. Lukianets, O. Dialogues of Cultures in Action. English language \& culture. Weekly. 2014. January, 2, 23 - 24 [in

19. Main, G. (2004). Peoples of a Spacious Land: Families and Cultures in Colonial New England. Cambridge; London: Harvard University Press [in English].

20. Martens, P. \& Rotmans, L. (2005). 'Transitions in a globalizing world', Futures 37, 1133-1144. 4, 15 [in English].

21. Martens, P. \& Zywietz, D. (2006), 'Rethinking globalization: a modified globalization index', Journal of International Development 18, 331-350. 5, 9 [in English].

22. Morris, M. (2004). Multicultural London: Melting pot of cultures. Speak out, 6, P.4 - 5 [in English].

23. Pop Culture Versus Real America (2010). New York: Bureau of International Information Programs U.S. Department of State [in English].

24. Role of Media in Promoting European Integration (2001). Kyiv: European Commission [in English].

25. Sysyn, F. I. (1988). History, Culture, and Nation: An Examination of Seventeenth-Century Ukrainian History Writing: brochure. Cambridge; Massachusetts: Ukrainian Studies Fund, Inc. [in English].

26. Toorn, Karel van der. (2007). Scribal Culture and the Making of the Hebrew Bible. Cambridge; London: Harvard University Press [in English].

27. Vinken, H. (2002), Cultures, Cities and Communications on the Pace and Place of Cultural Change, International ENIGME Workshop "Communication across Cultures in Multicultural Cities", The Hague, 7-8 November, available at: http://www.uvt.nl/iric. Abstract (accessed 4 December 2002) [in English].

28. Zakaria, N. (2000), "The effects of cross-cultural training on the acculturation process of the global workforce", International Journal of Manpower, 21, 6, $492-510$ [in English]

Стаття надійшла до редакції 07.06.2018 p. 